\title{
Sarcoidosis: histopathological definition and clinical diagnosis
}

\author{
D. N. MitChell, J. G. SCADDING, B. E. HEARD, AND K. F. W. HINSON
}

From Brompton Hospital, Fulham Road, London SW3 $6 H P$

SUMMARY Sarcoidosis is best defined in histopathological terms as 'a disease characterised by the presence in all of several affected organs and tissues of non-caseating epithelioid-cell granulomas, proceeding either to resolution or to conversion into hyaline connective tissue'.

Although the defining characteristics are thus histopathological, diagnosis during life depends largely upon clinical, radiological, and immunological findings. The amount of support required from histology varies greatly from case to case.

Though histology from one site cannot in itself establish the diagnosis of sarcoidosis, a generalised disease, detailed histological study of biopsy tissue makes an important and often essential contribution. In many instances, complete lack of necrosis, an intact reticulin pattern, and failure to demonstrate infective agents permit an unequivocal statement of compatibility with this diagnosis; however, a compatible clinical picture and absence of evidence of known causes of local granulomatous reactions or of other generalised granulomatous diseases are required for definitive diagnosis.

In some, the histological pattern deviates in some particular from the accepted 'typical' pattern; there may be a little necrosis, the follicular pattern of the granuloma may be less than perfect, and exclusion of known infective agents can never be absolute. In such instances, subsequent surveillance, including possible response to treatment, may show a clinical course justifying a diagnosis of sarcoidosis, and necropsy may establish it; but it must be recognised that in a few cases, particularly those in which the clinical evidence of disease is confined to one organ, diagnosis is likely to remain in doubt for long periods. Reports on the histology of the Kveim test should be made without knowledge of clinical findings and in terms of the presence and quality of granulomatous response. A granulomatous reaction to a validated test suspension makes a contribution to diagnosis similar to the finding of granulomas in an additional organ or tissue.

There is no general agreement about the definition of sarcoidosis. An international conference in 1960 could not agree on a formal definition and suggested instead 'a short descriptive paragraph' which has been widely used in place of a definition. While this referred to 'the characteristic histological appearance of epithelioid tubercles with little or no necrosis' the conference rejected the possibility of definition in histopathological terms on the grounds that this appearance is not pathognomonic, occurring in association with a number of infections by known agents, and as local reactions to foreign bodies and occasionally to malignant disease. But, historically, the observations that led to the concept of sarcoidosis as a systemic disease were (1) a non-caseating

Received for publication 5 January 1977 epithelioid cell granulomatosis not only in clinically affected organs and tissues but also, when sought, in some organs showing no clinical abnormality; and (2) the possible concurrence in individual patients of a great variety of involved organs. And, in current practice, it is the demonstration of these features that would convince informed observers faced with a doubtful case that it is correctly categorised as sarcoidosis. We therefore consider that a definition in terms of histopathology is useful and workable if it includes a reference to the involvement of several organs or tissues; sarcoidosis can be defined as 'a disease characterised by the presence in all of several affected organs and tissues of non-caseating epithelioid-cell granulomas, proceeding either to resolution or to conversion into hyaline connective tissue'. 
This definition is in qualitative terms and, in most cases, is not difficult to apply. But occasionally judgement on quantitative aspects of two elements in it is difficult. These are the proviso that several organs or tissues must be involved and the term 'non-caseating'.

The first of these may give rise to legitimate doubt and differences of opinion in clinical diagnosis, which is discussed later.

The second may give rise to difficulty because the distinction between non-caseating and caseating granulomas is not absolute. It is easy if there is no necrosis or if caseation is obvious; but some cases show minor degrees of necrosis and are difficult to categorise unequivocally in these terms. Experience has shown that some granular necrosis may be present at the centres of a few epithelioid and giantcell follicles in patients whose subsequent clinical course conforms to that associated with sarcoidosis; and it is generally accepted that minor changes of this sort are compatible with a diagnosis of sarcoidosis.

The suggested definition of sarcoidosis in terms of histopathology makes no reference to aetiology. Study of cases known to conform to this definition has shown that possible causal agents are unlikely to be isolated from them by a generally available technique. Nevertheless, if an agent that might be involved in pathogenesis is isolated from such a case, the definition does not require that the case be excluded from the category sarcoidosis; the possible role of the agent can be considered, even though this consideration may end in suspended judgement.

The purpose of this review is to discuss the histopathology and diagnosis of sarcoidosis, with special reference to these 'border-line' problems.

\section{Histopathology}

Most accounts of the histology of sarcoidosis refer to the monotonous uniformity of the appearance of the granulomas within the same or different tissues (Pinner, 1938). This uniformity has been overemphasised, possibly because the observations which suggested it were derived principally from postmortem examinations at which it would be expected that many of the granulomas would be of long standing. We have not infrequently observed different degrees of cellularity and fibrosis in the granulomas of a lymph node or other tissue obtained by biopsy from patients with clinical evidence of active sarcoidosis (Fig. 1a, b, and c). Turiaf (1964) has found that the granulomas present in the bronchial mucosa of patients with pulmonary mottling and probable fibrosis may continue to appear remarkably fresh. In a study of mediastinal lymph nodes obtained by mediastinoscopy fromo patients with bilateral hilar lymphadenopathy (BHL) with or without lung mottling, Mikhail et al. (1970)? found that the amount of hyaline fibrosis was poorlyo correlated with radiographic appearances and with duration of symptoms. Gross fibrosis was present in $\frac{\bar{p}}{\bar{\sigma}}$ some cases in which symptoms had appeared onlyळ recently, and radiographically the changes werew those of BHL alone, stage 1 of the conventionalclassification (Nitter, 1953). Patients with $\mathrm{BHL}_{-}^{\circ}$ associated with erythema nodosum (Löfgren's $\vec{\omega}$ syndrome) frequently showed confluent granulomas in which giant cells predominated (Fig. 2), and had용 positive Kveim tests with numerous confluentio epithelioid-cell granulomas, without excess of giantir cells. The mediastinal lymph nodes of some patientse् with BHL and pulmonary mottling or pulmonaryor mottling alone showed similar predominance of giant윽 cells. Thus, although some patients in all categoriesshowed an excess of giant cells in affected media- 3 stinal nodes, the proportion was highest among those in whom BHL was associated with erythemaco nodosum and/or febrile arthropathy. The presence $\checkmark V$ of eosinophilic necrosis of collagen in lymph node granulomas was not a characteristic of any particularo radiological state or racial group. Carlens et al. (1974) found pronounced granular necrosis which gave the impression of caseation in the granulomatous lymph $\frac{}{\circ}$ nodes obtained at mediastinoscopy from 15 of $250 \stackrel{\circ}{\Rightarrow}$ patients who presented with an acute febrile illnesso often accompanied by erythema nodosum or arth- $\frac{3}{2}$ ralgia but without overt BHL. Zettergren (1954) found that the necrobiotic lesion of the sarcoid $\stackrel{-}{-}$ granuloma, which is closely similar in appearance to that of caseous necrosis, was more prevalent in the granulomatous lesions of patients known to have 3 . recent sarcoidosis. The first detailed description of fibrinoid necrosis in sarcoid granulomas was given by Ricker and Clark (1949), who found this typeo of necrosis in $35 \%$ of 300 cases of sarcoidosis. They described areas of such necrosis in the centres ofo individual granulomas, but the greatest amount was found in areas where several granulomas coalesced. $\%$ Fibrinoid necrosis is strongly eosinophilic, fibrillar, $\mathbb{N}$ and acellular apart from a few intact lymphocytes N which may be present in the centre or at the periphery of the necrotic area. Silver staining may demonstrate

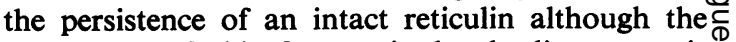
assessment of this feature in border-line cases is $\stackrel{?}{?}$ difficult and largely subjective. In fact it is accepted that some granular necrosis may be present at the $\bar{O}$ centres of or at the point of coalescence of a few $\overrightarrow{\mathbb{Q}}$ follicles without necessitating exclusion from the $\frac{}{\mathbb{Q}}$ category sarcoidosis.

Inclusion bodies, either crystalline or of the Schaumann conchoidal type, are frequently found in 


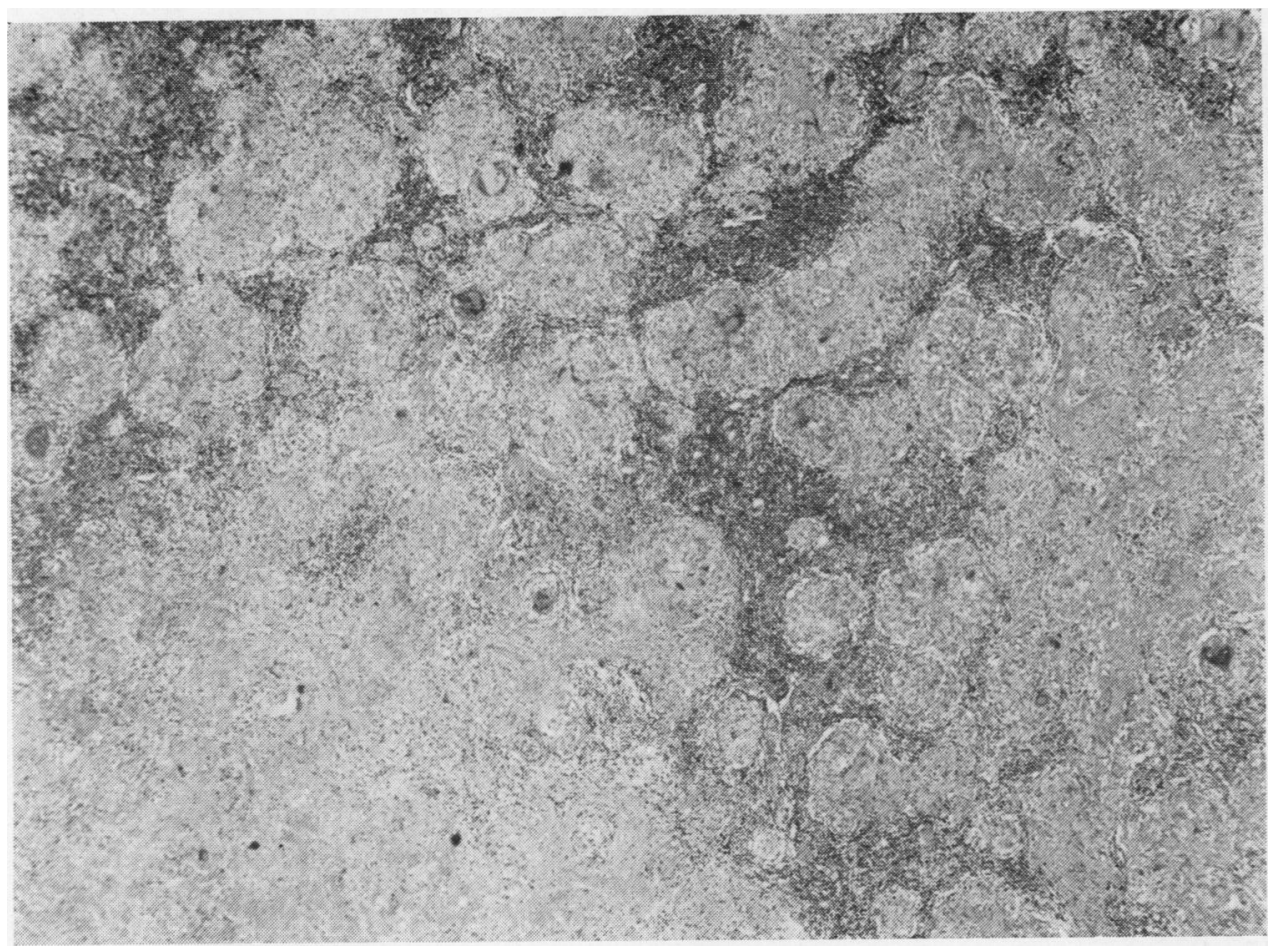

Fig. 1a

Fig. 1 Supraclavicular lymph node from a woman aged 53 who had had sarcoidosis with BHL and pulmonary infiltration for six years, showing (a) both fresh-looking granulomas (upper halfof photograph) and confluent hyalinising granulomas (lower half) [Haematoxylin and eosin $\times 53$ ]; (b) fresh-looking cellular granulomas [H and $E \times 133]$; and (c) granulomas and hyaline fibrosis [H and $E \times 1331$.

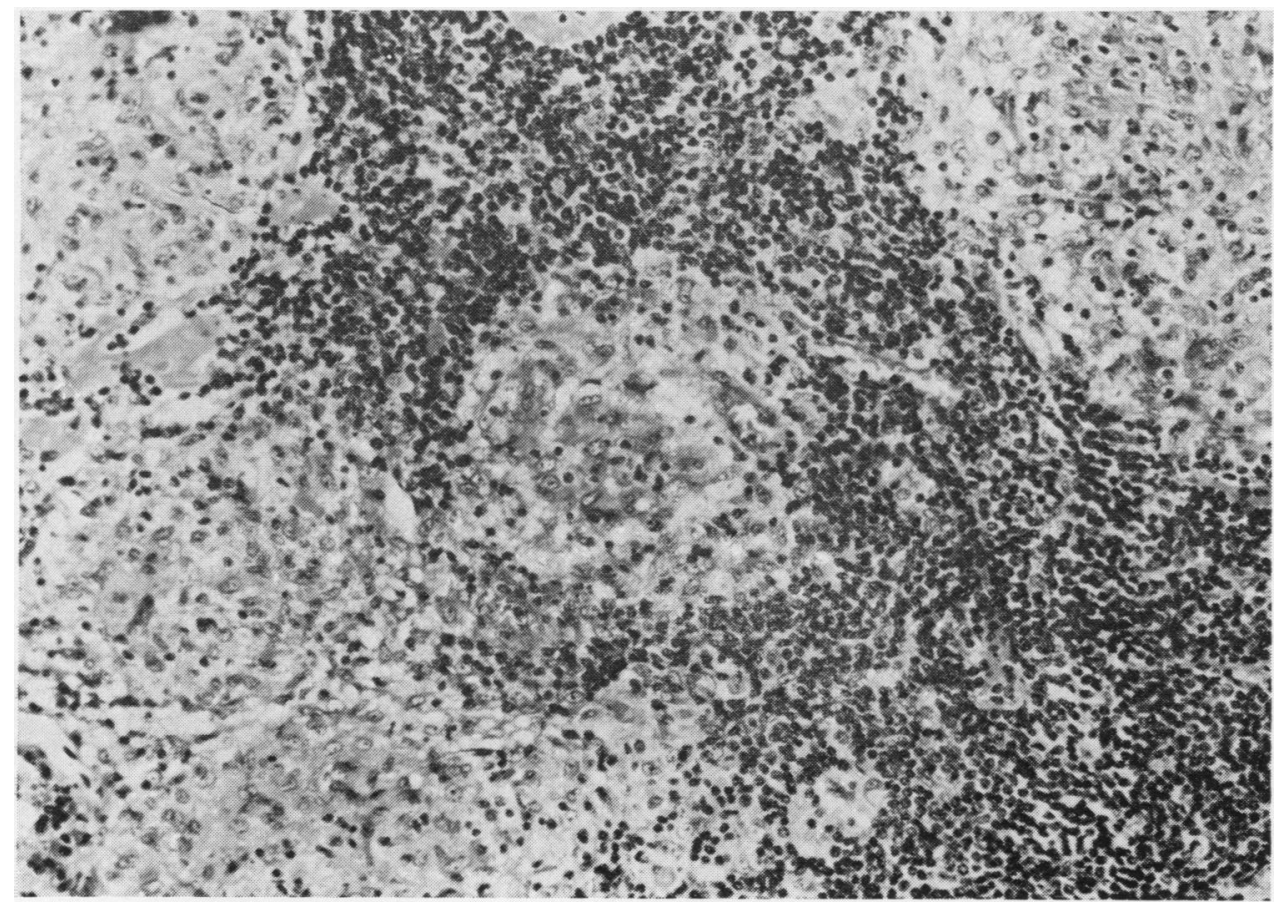

Fig. 1b 


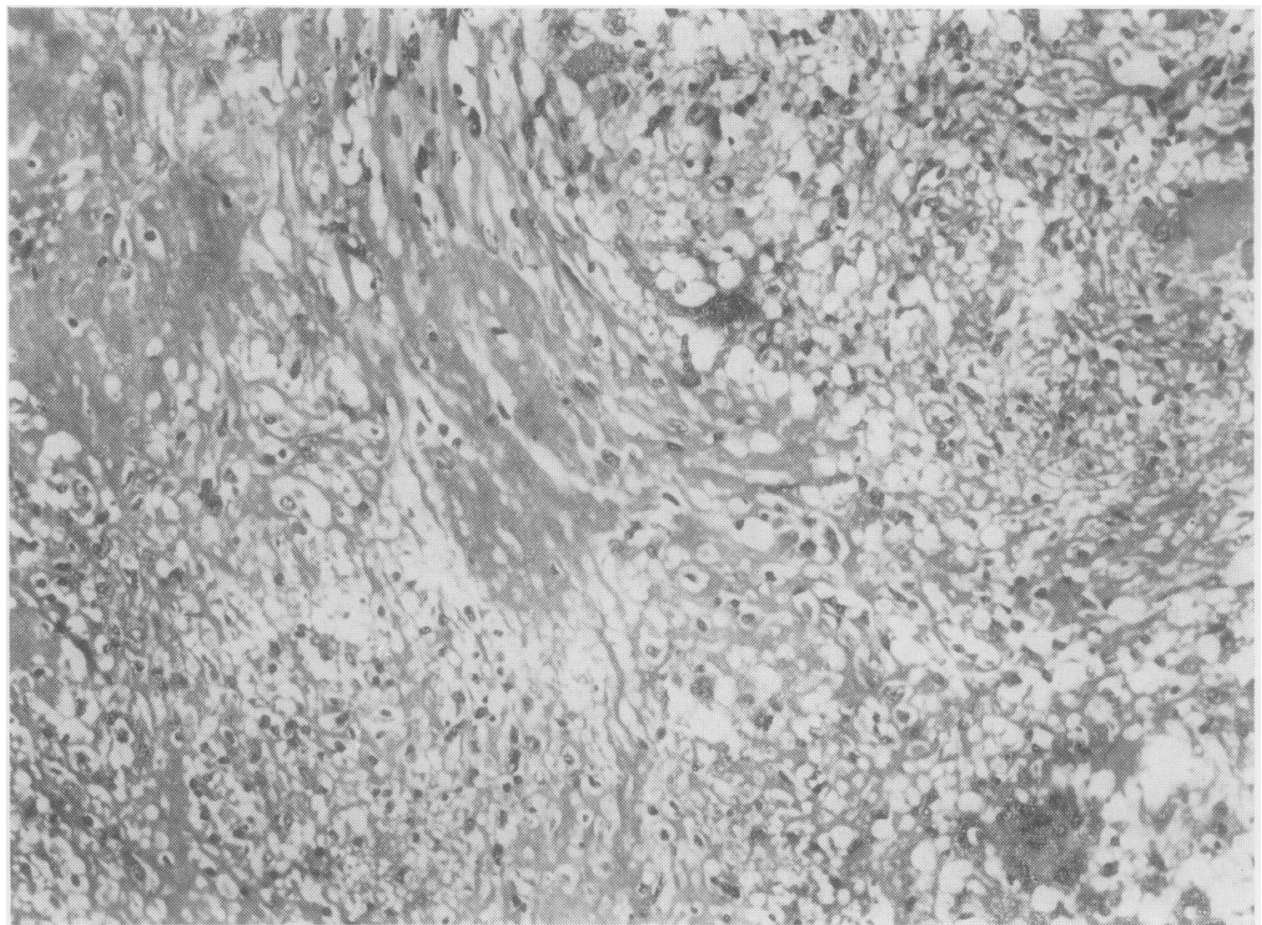

Fig. 1c

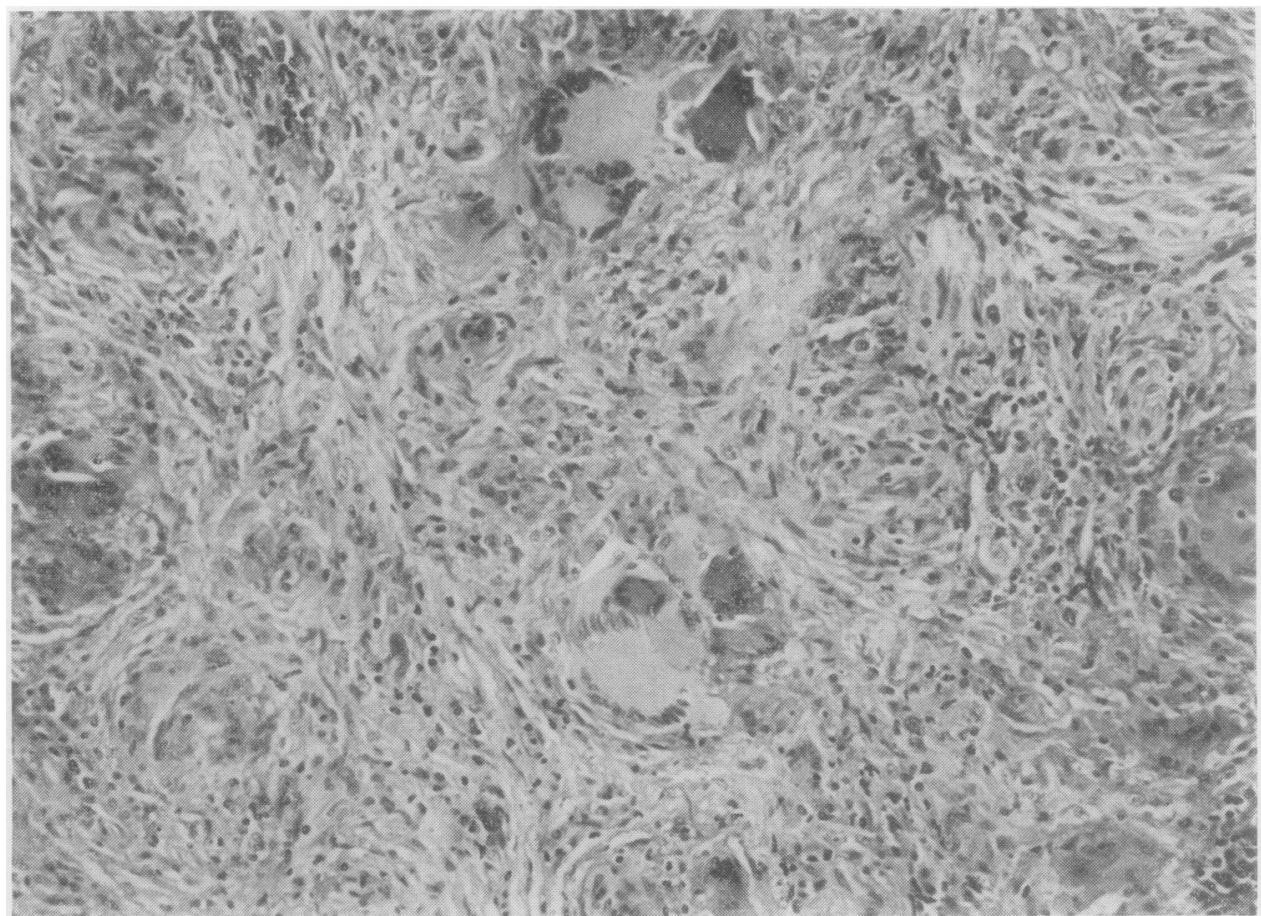

Fig. 2 Lymph node obtained by mediastinoscopy from a woman aged 35 with erythema nodosum and $B H L$, showing confluent granulomas with many giant cells [ $H$ and $E \times 133$ ]. 
the granulomas of sarcoidosis, especially in cases of long duration. They may also occur, though less frequently, in other granulomatoses. Thus Jones Williams (1960) found inclusions of one or both types in $88 \%$ of 17 cases of sarcoidosis, in $62 \%$ of 52 cases of chronic beryllium disease, and in only $6 \%$ of 100 cases of caseating tuberculosis. More recently, attention has been drawn to the presence of minute yellow-brown bodies in the lymph nodes of patients with sarcoidosis. These curious intracellular and extracellular structures vary in cross-sectional size from $3 \mu$ to $15 \mu$ and have been referred to by various investigators as Hamazaki-Wesenburg (Baro and Butt, 1969), yellow (Boyd and Valentine, 1970), curious (Carter et al., 1969), spiral (Wesenberg 1966), and spindle bodies (Hamazaki, 1938). Their exact nature is unknown. Doyle et al. (1973) found them in only $15 \%$ of the lymph nodes of their recorded cases of sarcoidosis, but they found them also in porta hepatis lymph nodes in three cases of alcoholic cirrhosis, in one case of carcinoma of the pancreas, and in one case of cholecystitis and cholelithiasis.

It is generally held that the finding of acid-fast bacilli on appropriate staining excludes a diagnosis of sarcoidosis. But acid-fast rods may be found in granulomatous tissues without caseation, or with minimal granular necrosis, from patients whose clinical course conforms to that of sarcoidosis. Thus Vaněk and Schwartz (1970), in a retrospective study of fixed material, found acid-fast rods of mycobacterial character on serial section of non-caseating epithelioid-cell granulomas present in cervical and epitrochlear lymph nodes. Cultures from the affected nodes in a few instances and from sputum, bone-marrow or urine in all cases were reported to have given negative results. In another retrospective study using fluorescent microscopy similar findings were reported by Richter et al. (1971). Greenberg et al. (1970) demonstrated inclusions which they suggested might be atypical forms or mutant variants of tubercle bacilli within the epithelioid cells of granulomas from lung biopsies of five patients with sarcoidosis. And very occasionally mycobacteria have been cultured from tissues containing noncaseating granulomas obtained from patients whose clinical picture conformed to that of sarcoidosis; for instance, Kent et al. (1970) isolated Mycobacterium tuberculosis from 19 of 30 patients with clinically definite sarcoidosis who showed non-caseating granulomas in peripheral lymph node or scalene node biopsies. It is relevant to these observations that Ziehl-Neelsen and auramine-rhodamine stained preparations are frequently negative in sections of caseating granulomatous lymph nodes that yield mycobacteria on culture. Evidently the distinction between caseating and non-caseating granulomas is not absolute, and its correlation with bacteriological findings is imperfect. Thus there is an area of uncertainty in which description of observations in as nearly quantitative terms as possible is desirable, and dogmatic categorisation should be avoided.

\section{Structure and functional activity of epithelioid and giant cells}

The only evidence from animal experiments that is relevant to the human sarcoid granuloma is derived from studies of granulomatous reactions in general and of the origin, kinetics, function, and fate of the epithelioid and giant cells of which they are composed. Sutton and Weiss (1966), in a study in which chicken monocytes transformed in tissue culture were studied by electron microscopy, demonstrated the cellular development of epithelioid cells from macrophages. Papadimitriou and Spector (1971) have confirmed that the precursor of the epithelioid cell is the highly phagocytic macrophage: there is good evidence that the macrophage originates from a circulatory cell of bone-marrow origin (Spector, 1969; van Furth, 1970). The differentiation of monocytes to macrophages is similarly well established (Cohn and Benson, 1965a, b). Ultrastructural studies of human sarcoid tissues (Hirsch et al., 1967; Wanstrup, 1967; Jones Williams, 1971; Spector, 1975) have shown that epithelioid cells have a convoluted plasmalemma, interdigitate closely, have abundant endoplasmic reticulum, contain a highly developed Golgi apparatus, and are therefore likely to have a secretory function. Moreover, Bernaudin et al. (1975) have shown that the characteristic vesicles of the epithelioid cell contain a glycoprotein substance which passes through the Golgi apparatus and accumulates in the lysosomes owing to their high content of acid phosphatase. Mariano and Spector (1974) studied multinucleate inflammatory giant cells obtained by allowing them to form from the macrophages which adhere to glass or plastic coverslips inserted subcutaneously into mice, and showed that these macrophage polykaryons have a life-span, as judged by their persistence on enclosed coverslips in vivo, of about six days.

They suggested that macrophage polykaryons form at sites of inflammation by fusion of newly arrived macrophages with macrophages already in situ, many of which are dividing and exhibit chromosomal abnormalities.

Ryan and Spector (1969) and Spector (1969) have shown that the inflammatory granulomas induced by different agents vary in the rate at which cells are replaced from the circulation and by mitotic division of the existing cells. Papadimitriou and 
Spector (1972) studied in mice the ultrastructure of three granulomas of known cellular kinetics. Reactions to carrageenan were composed of a homogenous population of stable, long-lived macrophages with a characteristic ultrastructure. Reactions to Bacillus pertussis vaccine were composed of a highly labile population of macrophages with rapid continuous recruitment of new cells from the marrow: the cells had the ultrastructural features of young macrophages and contained bacterial debris. Apart from some lymphocytes and fibroblasts, BCG granulomas were composed of cells of three ultrastructural types, epithelioid cells without phagocytic apparatus, young macrophages containing intact bacteria, and mature, possibly long-lived macrophages containing indigestible bacterial debris. In all three types of granuloma, the ultrastructural appearances of the cell population could be related closely to the known cellular kinetics of the lesion. Spector (1976), discussing granuloma turnover in relation to sarcoidosis, has pointed to the fact that epithelioid and giant cells are a feature of high turnover lesions and that it is reasonable to assume that sarcoidosis falls into this category; his studies in mice suggest that they are a poorly phagocytic but highly pinocytic version of the macrophage with a life span of one to three weeks, capable of mitosis, each epithelioid cell yielding two young macrophages.

Soler et al. (1976), in an ultrastructural study on serial sections of a small pulmonary sarcoid granuloma in man, have observed that the central cell population was mainly composed of typical epithelioid cells associated with fewer lymphoid cells; peripherally, monocytes, macrophages, and a few altered epithelioid cells were present. Monocytes and lymphocytes were found in the lymphatics present in the peripheral area.

Gordon (1975) has obtained quantitative data on the synthesis and extracellular secretion of lysozyme by mouse peritoneal macrophages in culture and found that activity increases with maturation of the cells. The process of maturation in culture is accompanied by so-called epithelioid changes (Sutton and Weiss, 1966; Papadimitriou and Spector, 1971), and there seems to be a case for correlating increased secretory activity of macrophages with the ultrastructural features of the epithelioid cell (Spector and Mariano, 1975).

Jones Williams et al. (1971) have compared the ultrastructure of epithelioid cells in non-caseating areas of tuberculous lymph nodes and in sarcoid lymph nodes. Among cells having the appearance of epithelioid cells on light microscopy, electron microscopy distinguished two main types, $\mathbf{A}$ and $\mathbf{B}$. B cells had lighter staining cytoplasm and less endoplasmic reticulum than A cells. In both sorts of lymph node, A and B cells were present; A cells were predominant in tuberculous granulomas, whereas B cells were predominant in sarcoid granulomas. The finding of transitional-cell forms that were difficult to classify as $\mathrm{A}$ or $\mathrm{B}$, the morphologic similarity of giant cells to B cells, the late development of giant cells in experimental granulomas (Sutton and Weiss, 1966); and the observation that dying cells were very pale, resembling $B$ rather than $A$ cells, suggested that $A$ and $B$ cells may represent stages in the development of one cell type. From the results of these ultrastructural and histochemical studies James and Jones Williams (1974) concluded that epithelioid cells in sarcoidosis and tuberculosis are biosynthetically active rather than phagocytic. Although these findings have not yet been repeated in other laboratories, recent observations on the levels of certain enzymes in the serum of patients with sarcoidosis and in sarcoid lymph nodes are compatible with this conclusion. Lysozyme has been found in abnormally high concentration in the serum of sarcoidosis patients (Pascual et al., 1973) and in sarcoid lymph nodes (Silverstein et al., 1975). Angiotensin-converting enzyme (ACE) has been reported to be raised in the serum of patients with active, but not in those with inactive, sarcoidosis (Lieberman, 1975; Silverstein et al., 1976); reports about the effect of corticosteroid treatment are conflicting. In patients with caseating tuberculosis and some other common diseases, ACE levels were normal; but high levels have been found in patients with Gaucher's disease, like sarcoidosis a disease in which the reticuloendothelial system is involved. Sarcoid lymph nodes contain much larger amounts of ACE than normal or caseating tuberculous lymph nodes. It is of course possible that cells of the macrophage series take up or retain ACE selectively; but biosynthetic activity of cells of the macrophage series in the sarcoid granuloma seems a more likely explanation.

Sarcoid granulomas frequently resolve completely, 을 but if they do not they become replaced, in whole or $N$ in part, by rather featureless hyaline connective tissue. Obel and Löfgren (1964) have shown that in $\mathcal{N}$ sarcoid lymph nodes hyaline is formed intra- $\underset{\omega}{ }$ cellularly in proliferating reticuloendothelial cells, around granulomas, and in islands in lymphatic 0 tissue; PAS positive granules appear in the cyto- $\bar{\varnothing}$ plasm and coalesce to form homogenous masses $\stackrel{\mathscr{f}}{+}$ which often contain cell nuclei. The hyaline re- $T$ sembles amyloid structurally but is not metachromatic.

\section{Clinical diagnosis}

A diagnosis of sarcoidosis is a statement of know- 
ledge or belief that the patient has a widespread 'non-caseating' epithelioid-cell granulomatosis. Certainty about the widespread nature of the granulomatosis can, of course, be attained only by necropsy or by an impossibly large number of biopsies. In practice, conformity with a characteristic clinical picture may permit the inference that there is a generalised non-caseating granulomatosis; and the amount of support this inference requires from histopathology varies inversely with the confidence with which the clinical picture is recognised. Many physicians are prepared to accept a working diagnosis of sarcoidosis without histological support in a patient with erythema nodosum or febrile arthropathy, bilateral hilar lymph-node enlargement (BHL), and low tuberculin sensitivity; and certainly histological evidence from a single site, or a Kveim test, would be regarded by the most critical as sufficient confirmation in such a case. But, at the other end of the range, there are rare cases presenting a bizarre clinical picture where doubt may remain even after biopsies from several sites have shown non-caseating granulomas; and a special problem is presented by certain cases in which the granulomatosis appears to involve one organ only.

\section{LUNG}

Lung biopsy, open, percutaneous or transbronchial, is now an established procedure in the diagnosis of widespread pulmonary infiltrations demonstrated radiologically. Sarcoidosis may present in this way. If clinical or other evidence of involvement of other organs by sarcoid-type granulomas is found, the diagnosis of sarcoidosis is generally accepted, but difficulties of interpretation arise when the only evidence is the finding of granulomas in a lung biopsy, especially if this is no more than the small fragment obtained by percutaneous or transbronchial procedures. Koerner et al. (1975) have described their experience with biopsy of the lung by flexible forceps during fibreoptic bronchoscopy, with fluoroscopic control to ensure that the pleura is not included in the material grasped by the forceps. Of 26 consecutive patients with clinical features of sarcoidosis, the histology showed noncaseating granulomas in 21 and normal lung in the remaining five. Of these five, two were found to have tuberculosis, one multiple pulmonary emboli, one sarcoidosis, and one remained without further evaluation. A diagnosis of sarcoidosis was accepted in the 21 patients who showed non-caseating granulomas, but of course this finding in a very small sample of lung tissue obtained by transbronchial biopsy can be no guarantee that in larger samples, or in other locations, caseation may not be present or mycobacteria or other organisms causing granu- lomatous inflammation demonstrable.

Occasionally non-caseating epithelioid-cell granulomas in the lung are accompanied by non-granulomatous inflammation, often taking the form of infiltration of alveolar walls by lymphocytes and plasma cells in the vicinity of the granulomas, possibly with hyperplasia of alveolar lining cells. Changes of this sort may occur in patients who have evidence of granulomatous changes at other sites, and in such instances the diagnosis of sarcoidosis is acceptable. If there is no evidence of involvement of other organs other possibilities must be considered. The combination of granulomatous changes with inflammatory changes in alveolar walls suggests extrinsic allergic alveolitis (Totten et al., 1958; Seal et al., 1968) and should lead to specific enquiry about possible exposure to organic dusts and appropriate immunological tests. If the granulomatous and inflammatory changes are accompanied by pulmonary angiitis, a range of histologically defined categories, which has been reviewed by Liebow (1973), should be considered. In some cases doubt about diagnosis may remain even after open lung biopsy and prolonged clinical observation (Fig. 3a, b, c).

\section{LIVER}

Sarcoidosis has been reported to involve the liver in some $63 \%$ of patients, but biochemical evidence of liver disease is usually minimal and clinical manifestations are rare. Occasionally hepatic sarcoidosis presents with clinical evidence of portal hypertension or of hepatic cellular damage (Porter, 1961; Mistilis et al., 1964; Maddrey et al., 1970). Corticosteroids do not always improve patients with hepatic sarcoidosis and may at times make them worse (Nelson and Schwabe, 1966).

Epithelioid-cell granulomas in the liver may be associated with a great variety of diseases of known and unknown cause. Klatskin (1976) found that, of 565 patients in whom such granulomas were found on liver biopsy, 319 had underlying granulomatous disease (sarcoidosis 217, tuberculosis 70, schistosomiasis 10 , others 13), 174 had underlying liver disease (cirrhosis 110, hepatitis 35, other 29), and 72 had diseases that were neither granulomatous nor primarily hepatic (intra-abdominal malignancy 15 , inflammatory bowel disease four, viral and bacterial infections eight, psoriasis eight, fever of unknown origin 17, other 20). The histological features of the hepatic granulomas were remarkably similar in all cases.

Israel and Goldstein (1973) reported the results of investigations in 30 patients who were found to have non-caseating hepatic granulomas in the presence of a normal chest radiograph. A diagnosis 


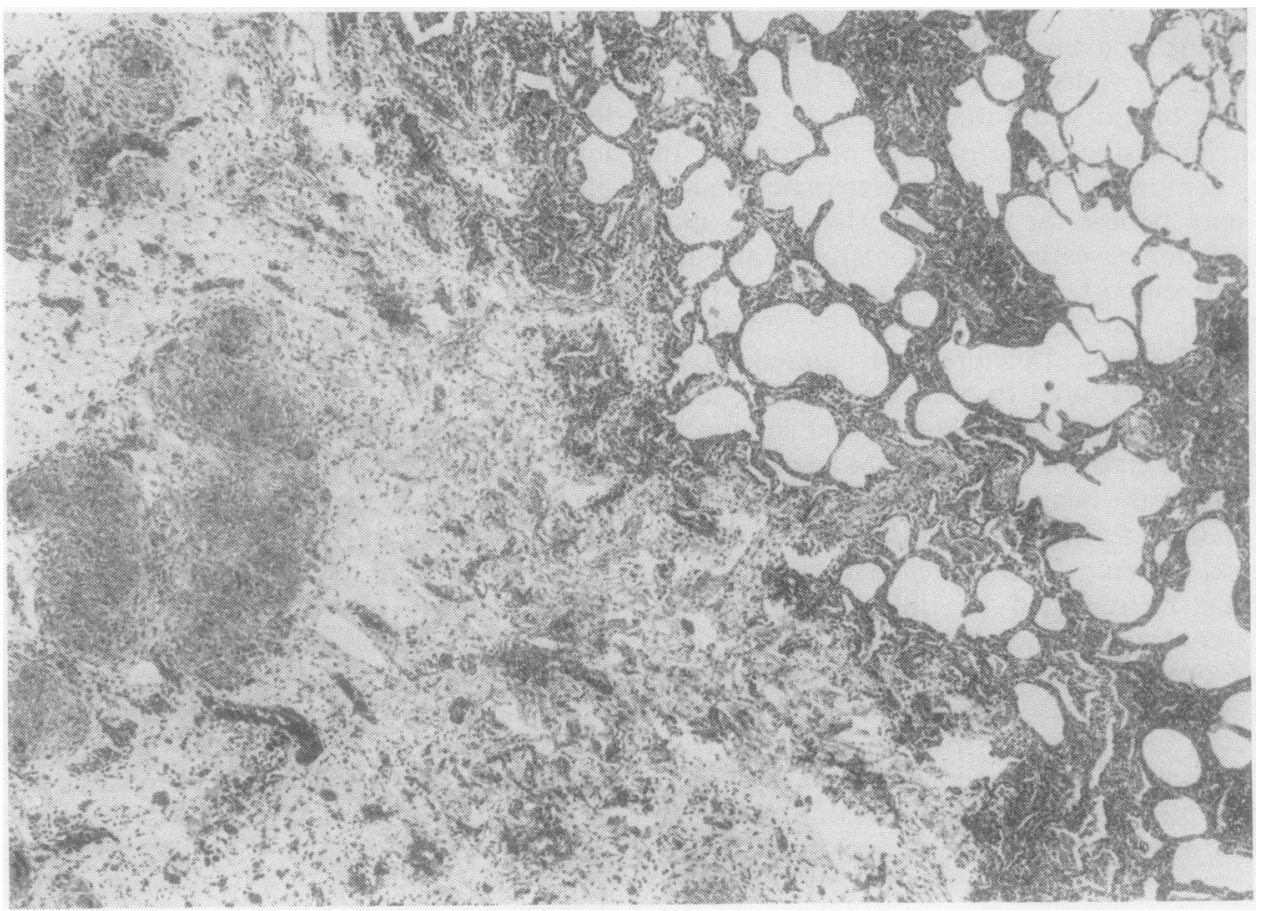

Fig. 3a

Fig. 3 Lung biopsy from a woman of 21, who presented with arthropathy, responding to antiinflammatory drugs, and increasing dyspnoea on exertion. Corticosteroid treatment led to rapid relief of dyspnoea and complete clearing of the chest radiograph. Withdrawal of the corticosteroid led to some return of joint symptoms, but the lungs remained clear during a four-year follow-up period. A Kveim test was interpreted as showing a foreign body reaction. The provisional diagnosis of sarcoidosis remains in doubt: (a) Non-caseating granulomas and fibrous tissue on the left and predominantly non-granulomatous inflammatory changes in alveolar walls on the right [H and $E \times 47] ;(b)$ higher magnification of granulomas shown in Fig. $3 a$ [H and $E \times 117]$; (c) higher magnification of inflammatory and minor granulomatous changes in alveolar walls shown in Fig. $3 a$ [H and $E \times 117]$.

of sarcoidosis appeared justified in nine of these patients by the demonstration of extra-abdominal granulomas or previous hilar lymphadenopathy. Of the remainder, seven with similar clinical features were found to have non-caseating granulomas in the spleen or abdominal lymph nodes and were considered as possible cases of sarcoidosis. Corticosteroids were consistently effective in the control of symptoms, but serial liver biopsy often showed little effect on the hepatic granulomas.

Simon and Wolff (1973) prospectively studied over 200 patients with prolonged recurrent fevers of unknown origin during the 12 years to 1973 . In this highly selected group many patients had unusual illnesses and required extensive investigation, often including liver biopsy. Of this series, 13 patients had granulomatous hepatitis with severe illness characterised by prolonged high fever. With the exception of one patient with portal hypertension and hepato- cellular failure, the symptoms and signs of liver disease were modest: liver biopsy in all these cases showed multiple hepatic granulomas. In one patient the granulomatous hepatitis probably represented a reaction to unsuspected Hodgkin's disease of the retroperitoneal lymph nodes, but the cause of illness in the other 12 patients remained obscure. All failed to respond to multiple antibiotics and nine to antituberculosis drugs. Corticosteroids were of great benefit to nine of 10 patients who received them: fever returned in two patients when the steroid dose was tapered, and two other patients had a return of fever and hepatic granulomas when steroids were discontinued.

Further confusing factors are that there is a granulomatous element in the histology of primary biliary cirrhosis (PBC), and that patients with sarcoidosis may be unusually liable to chronic liver disease of other kinds. Stanley et al. (1972) have 


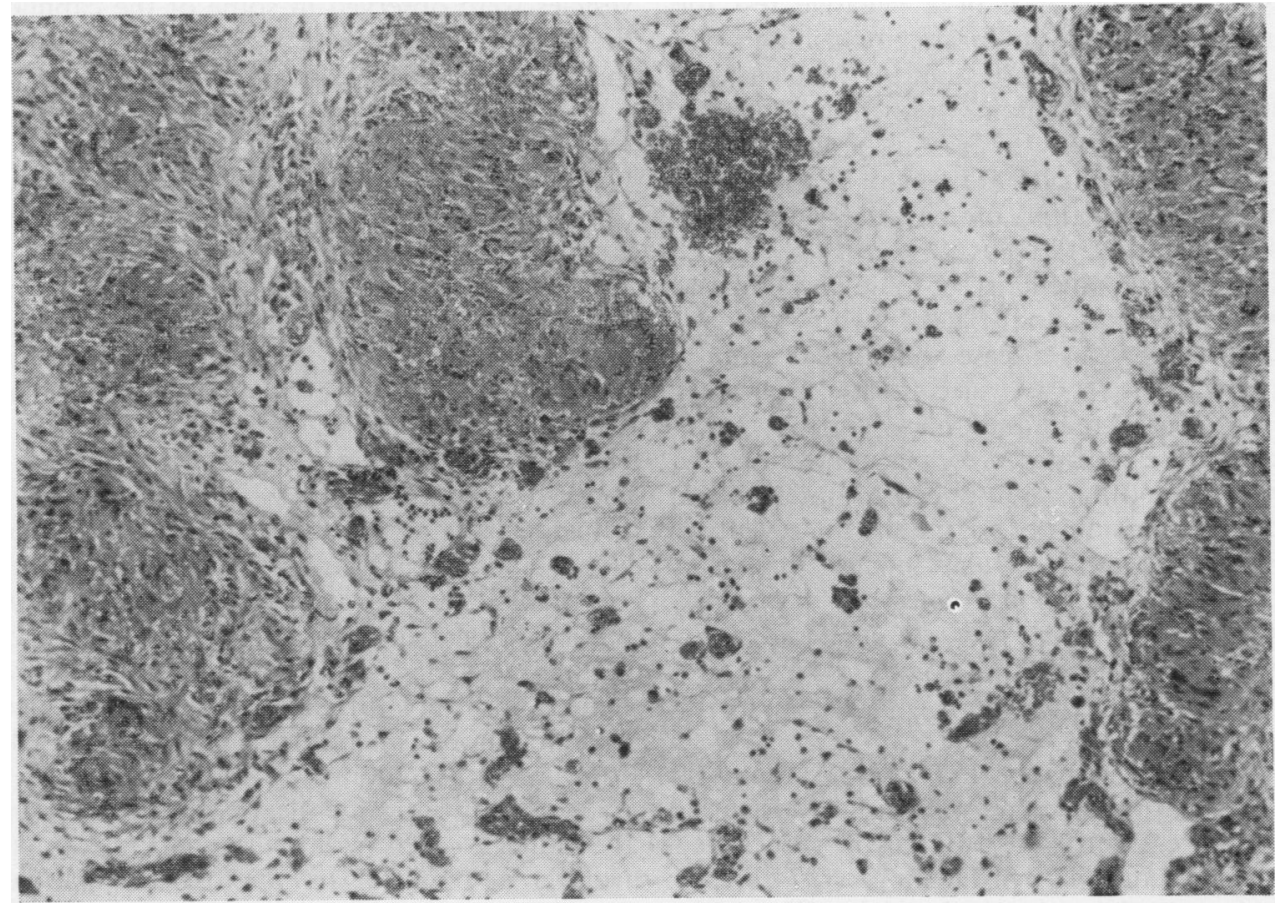

Fig. 3b

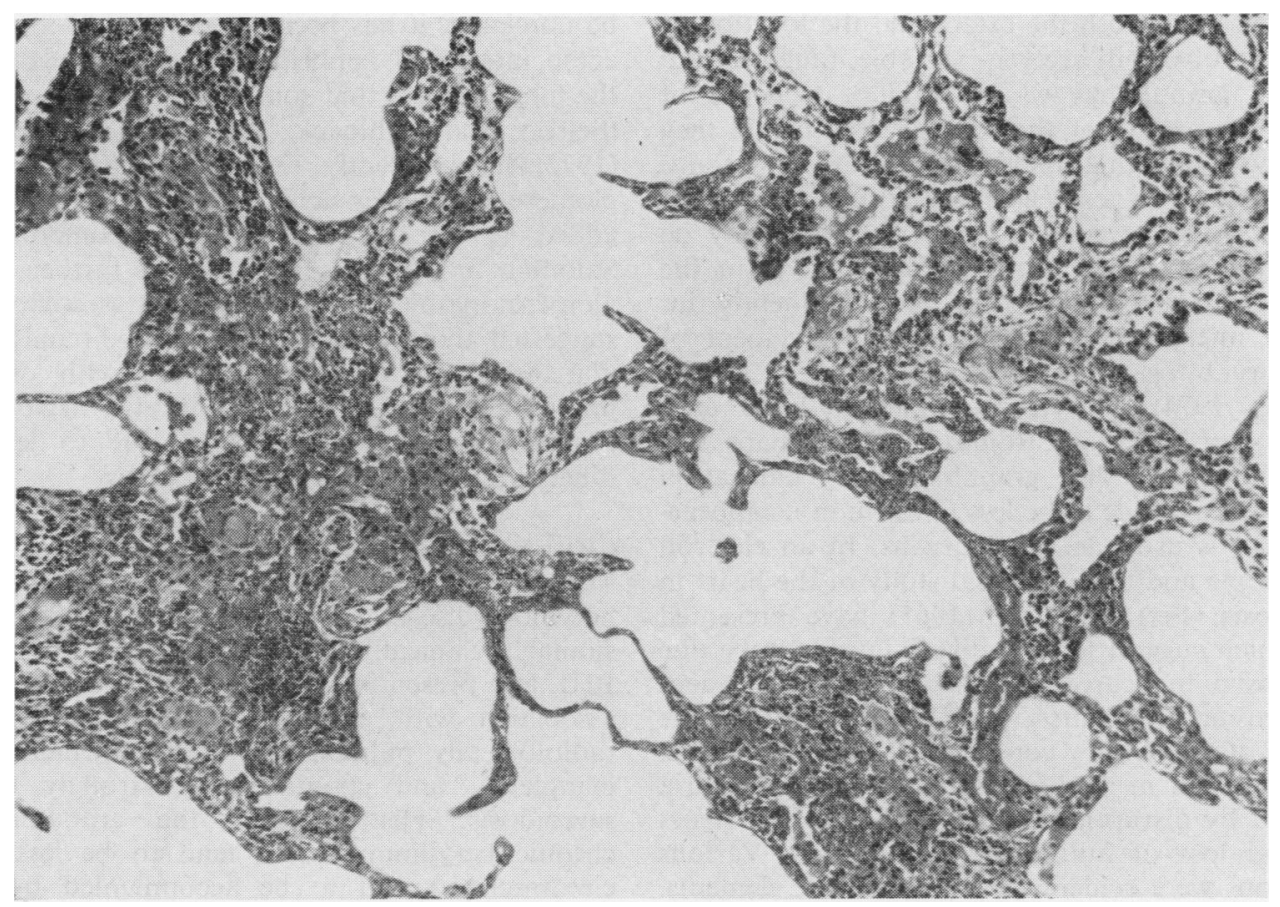

Fig. 3c 
emphasised the importance of a negative test for mitochondrial antibodies in distinguishing sarcoidosis from PBC; in more than $90 \%$ of patients with PBC the serum contains mitochondrial antibodies (Doniach et al., 1972). Antibodies against smooth muscle and nuclei are found in the serum of a smaller proportion of patients with PBC (Doniach and Walker, 1972). Rudzkiet al.(1975) have reported the development of chronic intrahepatic cholestasis in five young black men who had systemic granulomatous disease and clinical features consistent with those of sarcoidosis. Histology showed non-caseating granulomas, chronic intrahepatic cholestases, increased copper in hepatocytes, progressive diminution in number of interlobular bile ducts, periportal fibrosis, and the eventual development of a micronodular 'biliary' cirrhosis; but the characteristic nonsuppurative destructive cholangitis of PBC was not present and mitochondrial antibodies were not found.

\section{HEART}

A high proportion of the reported cases of sarcoidosis affecting the heart have been found at necropsy after sudden death, eg, 12 of the 50 cases in the United Kingdom summarised by Fleming (1974). The diagnosis is unlikely to be made during life unless there is evidence of involvement of other organs, and, although in some cases this is obvious, in others it is difficult to find. Both the extent and the location of cardiac involvement are very variable, ranging from scattered granulomas which produce evidence of their presence only if they are so placed that they affect the conducting tissues of the heart or produce dysrhythmias, to extensive replacement of myocardium. Even at necropsy the diagnosis may be overlooked unless sections are prepared from the ventricular septum which is most frequently infiltrated microscopically in minor involvement of the heart by sarcoidosis (Bashour et al., 1968; Fleming, 1974). In view of the rhythmic contractions of the myocardium, it is perhaps not surprising that the granulomatous infiltration observed in it tends to be less uniform in its appearance than is usual in other organs. In an electron microscopic and histochemical study of the heart in sarcoidosis, Ferrans et al. (1965) have presented data which suggest that cardiac failure may be due to extensive myocardial damage that is not evident by the usual techniques of histopathology, a large portion of which they considered to be irreversible. This consisted in swelling of muscle mitochondria followed by disruption of the mitochondrial structure and loss of mitochondrial enzymes. Various alterations were evident in the contractile elements. Lipid droplets and increased numbers of pinocytotic vesicles were observed in some of the capillaries of the heart, and numerous mast cells were found in the myocardium bordering the sarcoid granulomas.

\section{KIDNEY}

Hypercalcaemic nephropathy is the most frequent cause of renal failure in sarcoidosis. Granulomas are not infrequently found in renal biopsies (Löfgren et al., 1957; Lebacq, 1972), but granulomatous involvement extensive enough to cause renal failure has only rarely been reported. In patients with known sarcoidosis, the finding of granulomas in a kidney biopsy presents no problems of interpretation; but where the only available evidence concerns the kidney, provisional categorisation only is justified. In such cases the finding of granulomas elsewhere may be regarded as conclusive evidence of sarcoidosis. For instance, King et al. (1970) have reported a patient who, in the absence of clinical manifestations of sarcoidosis elsewhere, developed renal failure shown by biopsy to be associated with granulomatous interstitial nephritis: the demonstration of granulomas in the mediastinal lymph nodes, which were identical with those observed in the kidneys, confirmed that the patient was suffering from a systemic granulomatosis compatible with sarcoidosis.

Non-granulomatous nephritis may also occur in patients with sarcoidosis. While this may, of course, be unrelated, it has been suggested that a transient acute interstitial nephritis may be associated with the febrile illness that sometimes accompanies BHL (Selroos and Kuhlbäck, 1972). McCoy and Tisher (1972) have recently reviewed reported cases of glomerulopathy associated with sarcoidosis and added a case of membranous glomerulopathy. Salomon et al. (1975) reported a further case of glomerulopathy in a patient with sarcoidosis and suggested that, since sarcoidosis and renal glomerular disease are both associated with disturbed immunophysiology, the apparent rarity of glomerular disease in sarcoidosis may be due to less than diligent publication of pertinent cases.

\section{CHRONIC BERYLLIUM DISEASE}

The clinical and histological features of chronic beryllium disease (Tepper et al., 1961) are closely similar. Clinically, uveitis, erythema nodosum, BHL as a presenting feature, and bone cysts are not associated with chronic beryllium disease; and, radiologically, pulmonary infiltration which resolves completely and spontaneously strongly suggests sarcoidosis. Histologically, the granulomas in chronic beryllium disease tend to be less clearly circumscribed and to be accompanied by rather more general inflammatory changes than is usua 
in sarcoidosis. But, of four pathologists asked by Hardy (1956) whether they could distinguish histologically between sarcoidosis and chronic berylliosis, two admitted that they could not. Patients with beryllium disease are said to have negative Kveim reactions, but without information about the plan of the study upon which this opinion was based, $\mathrm{eg}$, whether the finding of a granulomatous reaction resulted in recategorisation as sarcoidosis, some doubt must remain. A review of the Beryllium Case Registry data at Massachusetts (Sprince et al., 1976) has added information making the distinction even more difficult. Among patients who were accepted as cases of chronic beryllium disease, two had isolated BHL, one had parotitis and central nervous system granulomas, and one cardiomyopathy. Beryllium was estimated in the lung tissue specimens of patients with sarcoidosis, beryllium disease, and controls. Beryllium levels in all six controls and in all five patients with sarcoidosis were below $0.02 \mu \mathrm{g} / \mathrm{g}$ dried weight. In 66 specimens from patients with beryllium disease, 54 had $0.02 \mu \mathrm{g} / \mathrm{g}$ or more, but 12 had less than $0.02 \mu \mathrm{g} / \mathrm{g}$. Thus, while a high tissue level of beryllium was correlated with the disease, low levels had little diagnostic significance.

\section{LOCAL 'SARCOID' REACTIONS}

James and Walker (1971) have discussed the many possible causes of a local sarcoid reaction and their differentiation from sarcoidosis; recently Brincker (1972) has again drawn attention to the finding of epithelioid-cell granulomas in the tissues of patients with Hodgkin's disease and other malignant lymphadenopathies. Occasionally these changes can be so extensive as to obscure the underlying pathology and may therefore be misleading (Fig. 4). The finding of a sarcoid-type granuloma at a site where it may be a local sarcoid reaction and not part of a generalised granulomatosis raises special difficulties, especially in a lymph node draining an area that may contain a malignant tumour. It has been stated that in patients with local sarcoid reactions the Kveim test is negative (Siltzbach, 1961) but this is based upon a relatively small number of observations, and further systematic study of it is required. It must be remembered that malignant disease (including lymphoma) and sarcoidosis may co-exist; several cases in which lymphoma has developed in

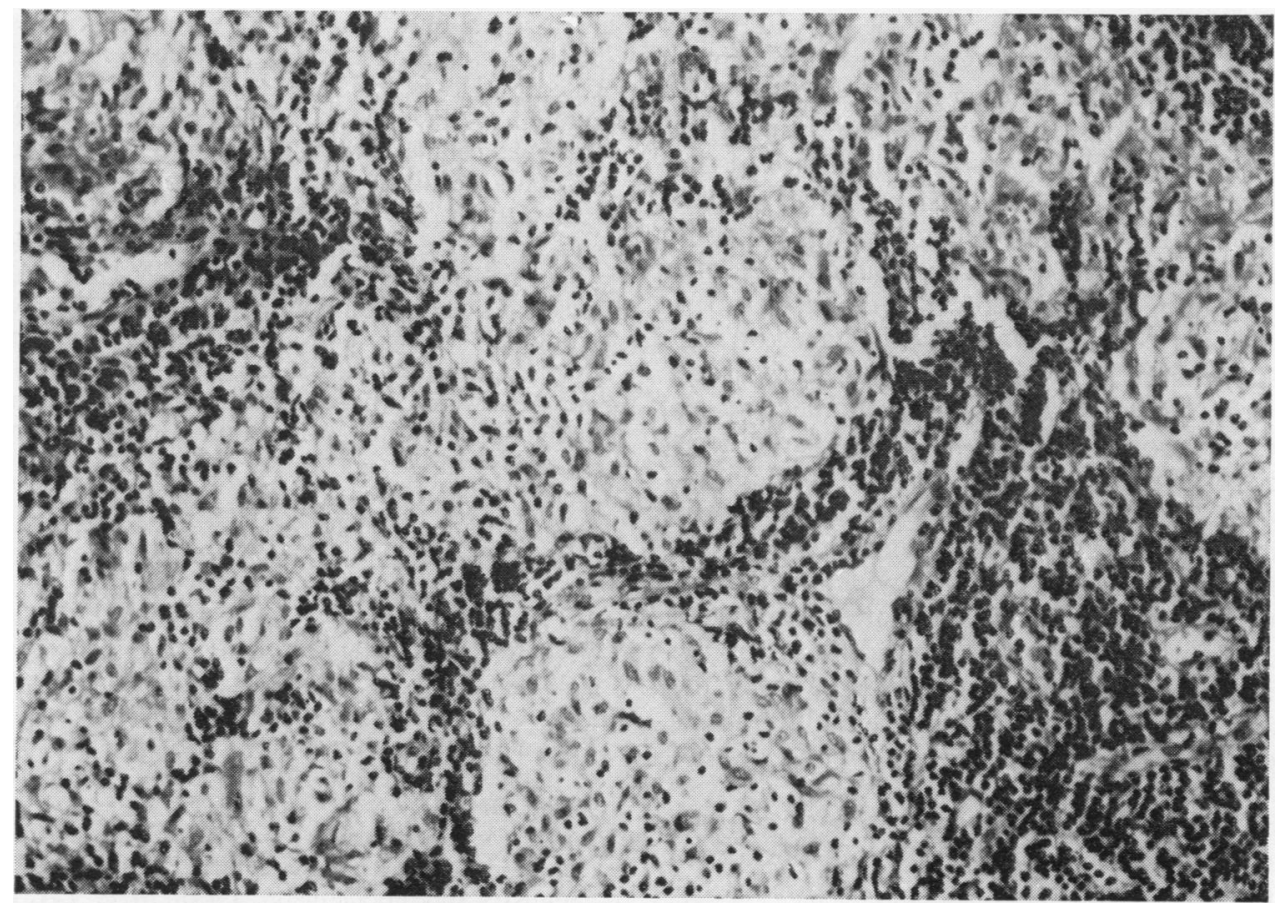

Fig. 4 Lymph node obtained by mediastonoscopy from a woman aged 56, showing many well-defined cellular granulomas. The patient died of an anaplastic carcinoma of the bronchus three months later; no evidence of granulomatosis was found in other lymph nodes, lung, liver, spleen, or myocardium [H and $E \times 133]$. 
patients with long-standing sarcoidosis have been recorded (Scadding, 1967), and Brincker and Wilbek (1974) found that the frequency of malignant lymphomata was 11 times the expected level.

The histology of local sarcoid reactions may be indistinguishable from that of generalisedsarcoidosis; diagnosis depends upon search on the one hand for evidence of granulomas in other sites, and on the other for possible causes of a local reaction.

\section{THE KVEIM TEST}

We do not propose to discuss here the histology of the Kveim reaction except to comment that, in our view, reports of the results of this test should be in terms of histological appearances. A scale ranging from unequivocally granulomatous, through partially granulomatous and simple inflammatory, to no reaction is appropriate. This does not, of course, exhaust the possible variations, and in some instances reports should refer to mixed reactions, or to such features as the presence of large numbers of giant cells, foreign material, especially birefringent, and necrosis. This histological report should be made without knowledge of the clinical features of the case.

The contribution of the Kveim test to diagnosis can be assessed in the light of knowledge of (1) the proportions of patients with sarcoidosis at various stages and with various leading manifestations who give a granulomatous response to the suspension used for the test: and (2) the clinical picture of the patient tested. In a patient with a clinical picture compatible with sarcoidosis, a granulomatous response increases and a non-granulomatous one diminishes the probability of this diagnosis to a degree varying with the apparent stage of the disease. In general, such a response may be regarded as the equivalent of finding granulomas in an additional location. If the probability of sarcoidosis is already very high, eg, in a patient with BHL, either symptomless or with erythema nodosum or febrile arthropathy, a granulomatous response to a Kveim test slightly increases this probability; but since it is known that from $10 \%$ to $15 \%$ of patients with this clinical presentation and with confirmation of the diagnosis by other histological evidence or by the subsequent course give a non-granulomatous response, a 'negative' reaction is almost noncontributory.

On the other hand, in patients with sarcoidosis at a chronic stage, clinically evident in one organ only, a granulomatous response to a Kveim test has been found to occur in only a minority, eg, $30 \%$ to $35 \%$ of those with a pulmonary infiltration without BHL. In this sort of case, a granulomatous response greatly increases the probability of the diagnosis of sarcoidosis, while its absence alters the probabilities very little.

The occurrence of granulomatous responses to some well-validated Kveim test suspensions (Mitchell et al., 1970; Mitchell et al., 1974) in patients with Crohn's disease and some other bowel diseases should cause no confusion because of the very different clinical features; but the possibility that they may occur in patients with certain forms of lymphadenopathy, including tuberculous but excluding Hodgkin's disease (Israel and Goldstein, 1971; Mikhail and Mitchell, 1971), must be borne in mind.

We thank Dr John F. Murray, Editor, American Review of Respiratory Disease, for permission to reproduce illustrations and other material from Sarcoidosis, State of the Art, American Review of Respiratory Disease, 110, 774-802, 1974. We are indebted to Miss Brenda Moore for secretarial assistance.

\section{References}

Bashour, F. A., McConnell, T., Skinner, W., and Hanson, M. (1968). Myocardial sarcoidosis. Dis. Chest, 53, 413-420.

Baro, C. and Butt, C. G. (1969). Hamazaki-Wesenberg bodies in sarcoidosis. Lab. Med., Bull. Pathol., p. 281. Cited by Doyle et al. (1973).

Bernaudin, J. F., Soler, P., Basset, F., and Chrétien, J. (1975) La cellule épithélioïde: données ultrastructurales au cours de diverses entités pathologiques humaines. Path. et Biol., 23, 494-498.

Boyd, J. F. and Valentine, J. C. (1970). Unidentified yellow bodies in human lymph-nodes.J.Path., 102, 59-60

Brincker, H. (1972). Sarcoid reactions and sarcoidosis in Hodgkin's disease and other malignant lymphomata Brit. J. Cancer, 26, 120-128.

Brincker, H. and Wilbek, E. (1974). The incidence of malignant tumours in patients with respiratory sarcoidosis. Brit. J. Cancer, 29, 247-251.

Carlens, E., Hanngren, A., and Ivemark, B. (1974). The concomittance of feverish onset of sarcoidosis and necrosis formation in the lymph nodes. In Proceedings of the VIth International Conference on Sarcoidosis, Tokyo, September 11-15, 1972, edited by K. Iwai and Y. Hosoda, pp. 409-312. University of Tokyo Press Tokyo. University Park Press, Baltimore.

Carter, C. J., Gross, M. A. and Johnson, F. B. (1969). The selective staining of curious bodies in lymph nodes of patients as a means for diagnosis of sarcoid. Stain Technology, 44, 1-4.

Cohn, Z. A. and Benson, B. (1965a). The differentiation of mononuclear phagocytes. Morphology, cytochemistry and biochemistry. J. exp. Med., 121, 153-170.

Cohn, Z. A. and Benson, B. (1965b). The in vitro differentiation of mononuclear phagocytes. II. The influence of serum on granule formation, hydrolase production and pinocytosis. J. exp. Med., 121, 835-848. 
Doniach, D., del Preta, S., Dane, D. S., and Walsh, J. H. (1972). Viral hepatitis related antigens in 'autoimmune' hepatic disorders. Canad. med. Ass. J., 106, Supplement, 513-518.

Doniach, D. and Walker, G. (1972). Immunopathology of liver disease. In Progress in Liver Diseases, edited by H. Popper and F. Schaffner, vol. 4, pp. 381-402. Grune and Stratton, New York.

Doyle, W. F., Brahman, H. D., and Burgess, J. H. (1973). The nature of yellow-brown bodies in peritoneal lymph nodes. Arch. Path., 96, 320-326.

Ferrans, V. J., Hibbs, R. G., Black, W. C., Walsh, J. J., and Burch, G. E. (1965). Myocardial degeneration in cardiac sarcoidosis. Histochemical and electron microscopic studies. Amer. Heart J., 69, 159-172.

Fleming, H. A. (1974). Sarcoid heart disease. Brit. Heart J., 36, 54-68.

Gordon, S. (1975). The secretion of lysozyme by mononuclear phagocytes. In Mononuclear Phagocytes in Immunity, Infection and Pathology, edited by $\mathbf{R}$. van Furth, pp. 387-403. Blackwell, Oxford.

Greenberg, S. D., Györkey, F., Weg, J. G., Jenkins, D. E., and Györkey, P. (1970). The ultrastructure of the pulmonary granuloma in 'sarcoidosis'. Amer. Rev. resp. Dis., 102, 648-652.

Hamazaki, Y. (1938). Uber ein neues, säurefeste Substanz führendes Spindelkörperchen der menschlichen Lymphdrüsen. Virchows Arch. Path. Anat., 301, 490-522.

Hardy, H. L. (1956). Differential diagnosis between beryllium poisoning and sarcoidosis. Amer. Rev. Tuberc., 74, 885-896.

Hirsch, J. G., Fedorko, M. E., and Dwyer, C. M. (1967). The ultrastructure of epithelioid and giant cells in positive Kveim test sites and sarcoid granulomata. In La Sarcoidose: Rapports de la IVe Conférence Internationale, Paris, 12-15 Septembre 1966, edited by J. Turiaf and J. Chabot, pp. 59-70. Masson, Paris.

Israel, H. L. and Goldstein, R. A. (1971). Relation of Kveim-antigen reaction to lymphadenopathy. New Engl. J. Med., 284, 345-349.

Israel, H. L. and Goldstein, R. A. (1973). Hepatic granulomatosis and sarcoidosis. Ann. intern. Med., 79, 669-678.

James, D. G. and Walker, A. N. (1971). All that glitters is not sarcoidosis. In La Sarcoidose, particulièrement dans ses Localisations Extrathoraciques: Rapports du Symposium Européen . . 23-25 Septembre 1971, edited by Y. Gallopin, pp. 113-116. Hallwag, Geneva.

James, E. M. V. and Jones Williams, W. (1974). Fine structure and histochemistry of epithelioid cells in sarcoidosis. Thorax, 29, 115-120.

Jones Williams, W. (1960). The nature and origin of Schaumann bodies. J. Path. Bact., 79, 193-201.

Jones Williams, W. (1971). The fine structure of Kveim granulomas and review of the Kveim test. In La Sarcoidose, particulièrement dans ses Localisations Extrathoraciques: Rapports du Symposium Européen ... 23-25 Septembre 1971, edited by Y. Gallopin, pp. 29-31. Hallwag, Geneva.

Jones Williams, W., Erasmus, D. A., Jenkins, D., James, E. M. V., and Davies, T. (1971). A comparative study of the ultrastructure and histochemistry of sarcoid and tuberculous granulomas. In 5th International Conference on Sarcoidosis, Prague, June 16-21, 1969, edited by L. Levinsky and F. Macholda, pp. 115-120. Universita Karlova, Prague.

Kent, D. C., Houk, V. N., Elliott, R. C., Sokolowski, J. W., Jr., Baker, J. H., and Sorensen, K. (1970). The definitive evaluation of sarcoidosis. Amer. Rev. resp. Dis., 101, 721-727.

King, B. P., Esparza, A. R., Kahn, S. I., and Garella, S. (1970). Sarcoid granulomatous nephritis occurring as isolated renal failure. Arch. intern. Med., 136, 241-245.

Klatskin, G. (1976). Hepatic granulomata: problems in interpretation. Ann. N. Y. Acad. Sci., 278, 427-432.

Koerner, S. K., Sakowitz, A. J., Appelman, R. I., Becker, N. H., and Schoenbaum, S. W. (1975). Transbronchial lung biopsy for the diagnosis of sarcoidosis. New Engl. J. Med., 293, 268-270.

Lebacq, E. (1972). Anomalies rénales anatomiques et fonctionnelles et perturbations du métabolism calcique dans la sarcoïdose. In La Sarcoidose, particulièrement dans ses Localisations Extrathoraciques: Rapports du Symposium Européen ... 23-25 Septembre 1971, edited by Y. Gallopin, pp. 155-157. Hallwag, Geneva. (Reprinted from Praxis (1972), 61, 628-630).

Lieberman, J. (1975). Elevation of serum angiotensinconverting-enzyme (ACE) level in sarcoidosis. Amer. J. Med., 59, 365-372.

Liebow, A. A. (1973). Pulmonary angiitis and granulomatosis. Amer. Rev. resp. Dis., 108, 1-18.

Löfgren, S., Snellman, B., and Lindgren, Å. G. H. (1957). Renal complications in sarcoidosis: functional and biopsy studies. Acta med. scand., 159, 295-305.

McCoy, R. C. and Tisher, C. C. (1972). Glomerulonephritis associated with sarcoidosis. Amer. J. Path., 68, 339-358.

Maddrey, W. C., Johns, C. J., Boitnott, J. K., and Iber, F. L. (1970). Sarcoidosis and chronic hepatic disease: a clinical and pathologic study of 20 patients. Medicine (Baltimore), 49, 375-395.

Mariano, M. and Spector, W. G. (1974). The formation and properties of macrophage polykaryons (inflammatory giant cells). J. Path., 113, 1-19.

Mikhail, J. R., Drury, R. A. B., and Mitchell, D. N. (1970). Evaluation of the clinical and histological features of paratracheal and hilar gland enlargement. Postgrad. med. J., 46, 515-518.

Mikhail, J. R. and Mitchell, D. N. (1971). Mediastinoscopy: a diagnostic procedure in hilar and paratracheal lymphadenopathy. Postgrad. med. J., 47, 698-704.

Mistilis, S. P., Green, J. R., and Schiff, L. (1964). Hepatic sarcoidosis with portal hypertension. Amer. J. Med., 36, 470-475.

Mitchell, D. N., Cannon, P., Dyer, N. H., Hinson, K. F. W., and Willoughby, J. M. T. (1970). Further observations on Kveim test in Crohn's disease. Lancet, 2, 496-498.

Mitchell, D. N., Hinson, K. F. W., Dyer, N. H., Willoughby, J. M. T., and Cannon, P. (1974). Some recent observations on the Kveim reaction. In Proceedings of the VIth International Conference on Sarcoidosis, Tokyo, September 11-15, 1972, edited by K. Iwai and Y. 
Hosoda, pp. 90-95. University of Tokyo Press, Tokyo. University Park Press, Baltimore.

Nelson, S. and Schwabe, A. D. (1966). Progressive hepatic decompensation with terminal hepatic coma in sarcoidosis. Report of a case. Amer. J. dig. Dis., 11, 495-501.

Nitter, L. (1953). Changes in the chest roentgenogram in Boeck's sarcoid of the lungs. Acta radiol. (Stockh.), Supplement, 105.

Obel, A. L. and Löfgren, S. (1964). Pathogenesis of hyaline formation in sarcoidotic lymph nodes. Acta med. scand., Supplement, 425, 27-32.

Papadimitriou, J. M. and Spector, W. G. (1971). The origin, properties and fate of epithelioid cells. J. Path., 105, 187-203.

Papadimitriou, J. M. and Spector, W. G. (1972). The ultrastructure of high- and low-turnover inflammatory granulomata. J. Path., 196, 37-43.

Pascual, R. S., Gee, J. B. L., and Finch, S. C. (1973). Usefulness of serum lysozyme measurement in diagnosis and evaluation of sarcoidosis. New Engl. J. Med., 289, 1074-1076.

Pinner, M. (1938). Noncaseating tuberculosis. Amer. Rev. Tuberc., 37, 690-728.

Porter, G. H. (1961). Hepatic sarcoidosis. A cause of portal hypertension and liver failure, review. Arch. intern. Med., 108, 483-495.

Richter, J., Barták, F., and Hálová, R. (1971). Detection of mycobacteria by fluorescent microscopy in sarcoidosis. In 5th International Conference on Sarcoidosis, Prague, June 16-21, 1969, edited by L. Levinský and F. Macholda, pp. 83-84. University Karlova, Prague.

Ricker, W., and Clark, M. (1949). Sarcoidosis: a clinicopathologic review of 300 cases, including twenty-two autopsies. Amer. J. clin. Path., 19, 725-749.

Rudzki, C., Ishak, K. G., and Zimmerman, H. J. (1975). Chronic intrahepatic cholestasis of sarcoidosis. Amer. J. Med., 59, 373-387.

Ryan, G. B. and Spector, W. G. (1969). Natural selection of long-lived macrophages in experimental granulomata J. Path., 99, 139-151.

Salomon, M. I., Poon, T. P., Hsu, K. C., King, E. J., and Tchertkoff, V. (1975). Membranous glomerulopathy in a patient with sarcoidosis. Arch. Path., 99, 479-483.

Scadding, J. G. (1967). Sarcoidosis. Eyre and Spottiswoode, London.

Seal, R. M. E., Hapke, E. J., Thomas, G. O., Meek, J. C., and Hayes, M. (1968). The pathology of the acute and chronic stages of farmer's lung. Thorax, 23, 469-489.

Selroos, O. and Kuhlbäck, B. (1972). Renal involvement in sarcoidosis. In La Sarcoidose, particulièrement dans ses Localisations Extrathoraciques: Rapports $d u$ Symposium Européen ... 23-25 septembre 1971, edited by Y. Gallopin, pp. 158-163. Hallwag, Geneva.

Siltzbach, L. E. (1961). The Kveim test in sarcoidosis: a study of 750 patients. J. Amer. med. Ass., 178, 476-482.

Silverstein, E., Friedland, J., and Ackerman, T. (1975). Elevated lysozyme activity in non-necrotizing granulomatous lymph-nodes in sarcoidosis. Clin. Res., 23, $600 \mathrm{~A}$.

Silverstein, E., Friedland, J., Lyons, H. A., and Gourin, A. (1976). Evaluation of angiotensin-converting enzyme in granulomatous lymph nodes and serum in sarcoidosis: clinical and possible pathogenic significance. Ann. N. Y. Acad. Sci., 278, 498-513.

Simon, H. B. and Wolff, S. M. (1973). Granulomatous hepatitis and prolonged fever of unknown origin: a study of 13 patients. Medicine, (Baltimore), 52, 1-21.

Soler, P., Basset, F., Bernaudin, J. F, and Chrétien, J. (1976). Morphology and distribution of the cells of a sarcoid granuloma: ultrastructural study of serial sections. Ann. N. Y. Acad. Sci., 278, 147-160.

Spector, W. G. (1969). The granulomatous inflammatory exudate. Int. Rev. exp. Path., 8, 1-8.

Spector, W. G. (1975). The dynamics of granulomas and the significance of epithelioid cells. Path. et Biol., 23, 437-439.

Spector, W. G. (1976). Epithelioid cells, giant cells, and sarcoidosis. Ann. N. Y. Acad. Sci., 278, 3-6.

Spector, W. G. and Mariano, M. (1975). Macrophage behaviour in experimental granulomas. In Mononculear Phagocytes in Immunity, Infection and Pathology, edited by R. van Furth, pp. 927-938. Blackwell, Oxford.

Sprince, N. L., Kazemi, H., and Hardy, H. L. (1976). Current (1975) problem of differentiating between beryllium disease and sarcoidosis. Ann. N. Y. Acad. Sci., 278, 654-664.

Stanley, N. N., Fox, R. A., Whimster, W. F., Sherlock, S. and James, D. G. (1972). Primary biliary cirrhosis or sarcoidosis-or both. New Engl. J. Med., 287, 12821284.

Sutton, J. S. and Weiss, L. (1966). Transformation of monocytes in tissue culture into macrophages, epithelioid cells, and multi-nucleated giant cells. J. Cell Biol., 28, 303-332.

Tepper, L. B., Hardy, H. L., and Chamberlin, R. I. (1961). Toxicity of Beryllium Compounds. Elsevier, Amsterdam.

Totten, R. S., Reid, D. H. S., Davis, H. D., and Moran, T. J. (1958). Farmer's lung: report of two cases in which lung biopsies were performed. Amer. J. Med., 25, 803-809.

Turiaf, J. (1964). Bronchial sarcoidosis. Acta med. scand. Supplement, 425, 228-229.

Vaněk, J. and Schwartz, J. (1970). Demonstration of acidfast rods in sarcoidosis. Amer. Rev. resp. Dis., 101, 395-400.

van Furth, R. (1970). The origin and turnover of promonocytes, monocytes and macrophages in normal mice. In Mononuclear Phagocytes, edited by R. van Furth, pp. 151-165. Blackwell, Oxford.

Wanstrup, J. (1967). On the ultrastructure of granuloma formation in sarcoidosis. In La Sarcoidose: Rapports de la IVe Conférence Internationale, Paris, 12-15 septembre 1966, edited by J. Turiaf and J. Chabot, pp. 110-116. Masson, Paris.

Wesenberg, W. (1966). Tönsheide: über säurefeste 'Spindelkörper Hamazaki' bei Sarkoidose der Lymphknoten und über doppellichtbrechende Zelleinschlüsse bei Sarkoidose der Lungen. Arch. klin. exp. Derm., 227, 101-107.

Zettergren, L. (1954). Lymphogranulomatosis benigna. A clinical and histo-pathological study of its relation to tuberculosis. Acta Soc. Med. 'upsalien., Supplement 5,95 . 